\title{
HYDROXYACETOPHENONE DERIVATIVES AND CHROMENE - EUPARIN DIMERS FROM ENCELIA PALMERI
}

\author{
Taha M. Sarg, Sameeh I. El-Dahmy, Hosny Abd El-Fattah* \\ and Mahmoud Abd El-Aal* \\ Pfarmacognosy Department, Facufty of Pfiarmacy, Zagazig University, Egypt. \\ - Tharmacognosy Department, Faculty of Tharmacy, Al-Fateft Znitersity, Tripofi, Libya.
}

\begin{abstract}
Investigation of the petroleum ether-ether extract of Encelia palmeri afforded four mixed dimers of euparin and encecalin. Further, derivatives of euparin, encecalin, B-sitosterol, stigmasterol and B-farnesene were also isolated. The structure of these compounds was elucidated on basis of spectral methods and direct comparison of their spectral data with those of authentic compounds (co-TLC and m.p.).
\end{abstract}

\section{INTRODUCTION}

The genus Encelia (Compositae, Tribe Heliantheae) is classified in the larger subtribe Ecliptinae ${ }^{(1)}$. Many species from the genus have been studied for their chemical constituents ${ }^{(2-8)}$, indicated the presence of serveral hydroxyacetophenone derivatives. This class of compounds has demonstrated different biological activities. The benzofuran derivatives showed bacteriostatic and antitumor activity. It also implicated as the causative agents of milk sickness and toxic principles to goldfish ${ }^{(9)}$.

In a recent study ${ }^{(9)}$, the encealin and eurparin derivatives were found to be phototoxic to several fungi and bacteria. In addition, precocenes I and II proved to act as anti-juvenile hormones against certain types of insects. Currently, no records have been found on the phytochemical investigations of this species. Thus, it was deemed of interest to investigate this plant in order to isolate and identify the available constituents, which might have potential activity or chemical importance as well.

\section{EXPERIMENTAL}

\section{Material and methods :}

The plant material was collected from Mexico (March, 1989) and kindly authenticated by Prof. D.H. Robinson and Dr. R. King, Smithonian Institution, Washington, USA. 'Hnmr spectra were recorded (in $\mathrm{CDCl}_{3}$ ) with Bruker WM400. Mass spectra were recorded on Varian-Mat 335, at $70 \mathrm{ev}$, by direct inlet technique. Infrared spectra were recorded on Perkin Elmer infrared spectrophotomer $720\left(\mathrm{C} \mathrm{Cl}_{4}\right)$.

\section{Extraction and isolation :}

The air-dried plant material (aerial part, $600 \mathrm{~g}$ ) was exhaustively extracted with ether-petroleum ether $(1: 2)$. The resulting extract was concentrated under reduced pressure. The obtained residue $(8.2 \mathrm{~g})$ was fractionated on column chromatography (silicic acid) into four major fractions:

Fraction 1: eluted with petroleum ether $(100 \%)$ to yicld $0.985 \mathrm{~g}$. 
Fraction II: eluted with petroleum ether-ether $(9: 1)$ to yield $1.2 \mathrm{~g}$.

Fraction III: eluted with petroleum ether-ether (7.5:2.5) to yield $2.3 \mathrm{~g}$.

Fraction IV: elued with petroleum ether-ether $(1: 1)$ to yield $1.5 \mathrm{~g}$.

Constituents of fraction $I$ and II: through P'TLC, $\left(\mathrm{SiO}_{2}, \mathrm{PF}_{245}\right)$, using petroleum ether $100 \%$ afforded $105 \mathrm{mg}$ of B-farnesene (co-tlc, nmr.).

Constituents of fraction III: by flash chromatography using $\mathrm{SiO}_{2}, 80 \mu, 3$ bar, with petroleum ether-ether $3: 1$ gave three fractions. Fraction IIIa, through PTLC $\left(\mathrm{SiO}_{2}\right.$, petroleum ether-ether $\left.3: 1\right)$ gave $10 \mathrm{mg}$ of compound 3 . Fraction III b, gave by PTLC $\left(\mathrm{SiO}_{2}\right.$, petroleum etherether, $2: 1,2$ runs) gave $6 \mathrm{mg}$ of compound 2. Fraction III $\mathbf{c}$, by using PTLC $\left(\mathrm{SiO}_{2}\right.$, petroleum ether-ether, $2: 1,2$ runs) afforded $20 \mathrm{mg}$ of mixture of 5 and $\mathbf{6}$. By repeated PTLC $\left(\mathrm{SiO}_{2}\right.$, benzene-ether 9:1) gave $5 \mathrm{mg}$ of 5 and $9 \mathrm{mg}$ of $\mathbf{6}$.
Constituents of fraction IV: by using flash chromatography $\left(\mathrm{SiO}_{2}, 80 \mu, 3\right.$ bar, petroleum ether-ether 1:1) afforded three fractions. Fraction IV a, by using PTLC $\left(\mathrm{SiO}_{2}\right.$, petroleum ether-ether, 1:1, 2 runs) gave $11 \mathrm{mg}$ of 4 and $2 \mathrm{mg} 1$. Fraction IV b, by PTLC $\left(\mathrm{SiO}_{2}\right.$, petroleum ether-ether $1: 1$ ) gave mixture of $B$ sitosterol and stigmasterol. Fraction IV c, by PTLC $\left(\mathrm{SiO}_{2}\right.$, petroleum ether-ether (1:2) gave $15 \mathrm{mg}$ of compound 1 and 35 $\mathrm{mg}$ of mixture of 7 and 8 .

\section{RESULTS AND DISCUSSION}

The ethereal extract of aerial parts of Encelia palmeri Vasey \& $\mathrm{N}$ by using different methods of chromatography afforded B-sitosterol, stigmasterol, Bfarnesene and several hydroxy acetophenone derivatives; eurparin 1, chromones 2-4 and the dimeric compounds 5-8. The structure of compounds 1 and 2 was deduced from the ${ }^{1} \mathrm{Hnmr}$ spectral data (Table 1) through comparison with reported data of euparin and encecalin ${ }^{(4,6)}$.

\section{Table (1): ${ }^{1} \mathrm{Hnmr}$ spectral data of compounds $1-4\left(400 \mathrm{MHz}, \mathrm{CDCl}_{3}\right.$, TMS as internal standard).}

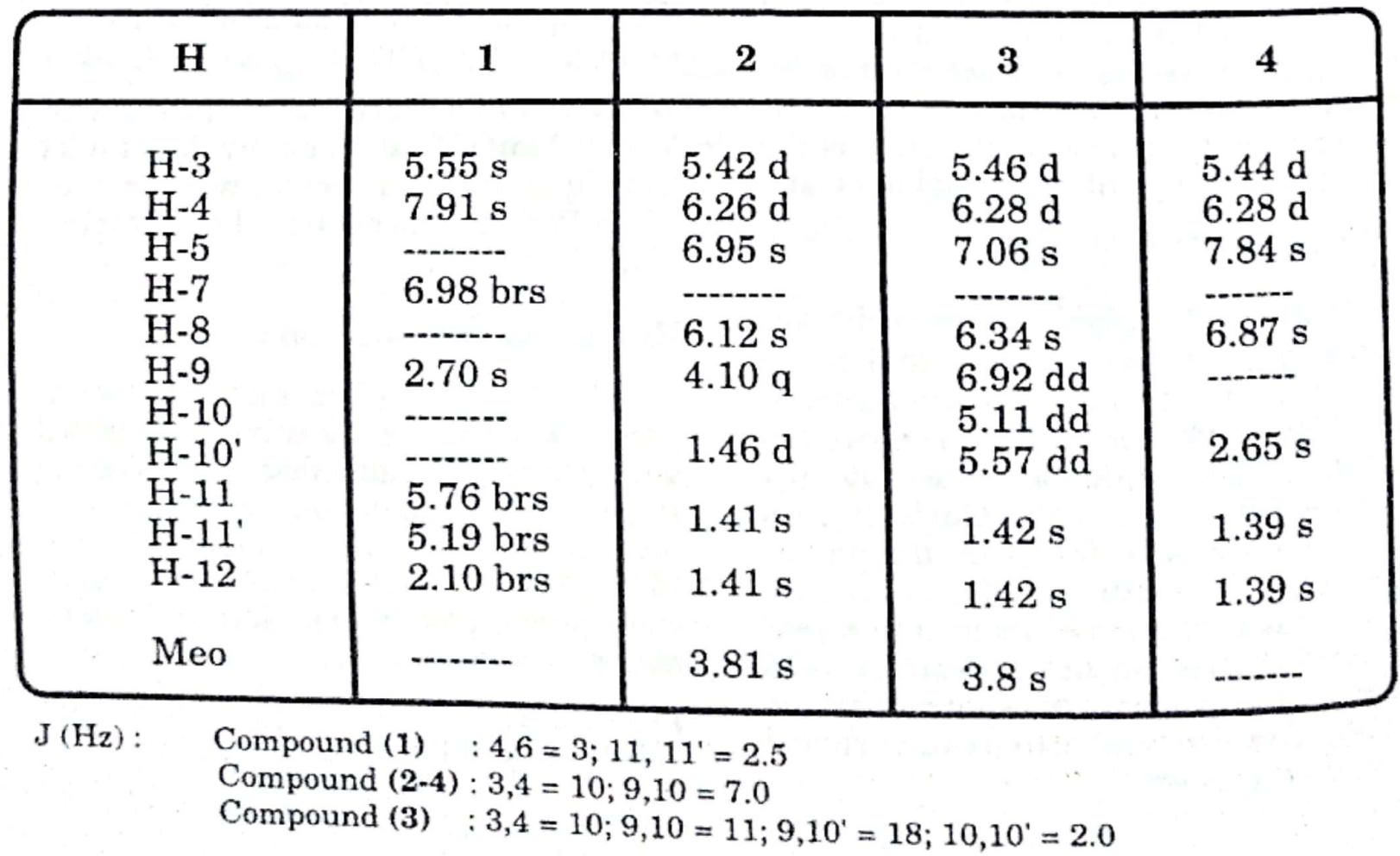


Table (2): ${ }^{1} \mathrm{Hnmr}$ spectral data of compounds 5-8 (400 $\mathrm{MHz}, \mathrm{CDCl}_{3}$, TMS as internal standard).

\begin{tabular}{|c|c|c|c|c|}
\hline H & 5 & 6 & 7 & 8 \\
\hline $\mathrm{H}-3$ & $6.44 \mathrm{brs}$ & $6.72 \mathrm{brs}$ & $6.44 \mathrm{brs}$ & $6.16 \mathrm{brs}$ \\
\hline $\mathrm{H}-4$ & $7.85 \mathrm{~s}$ & $7.91 \mathrm{~s}$ & $7.86 \mathrm{~s}$ & $7.72 \mathrm{~s}$ \\
\hline $\mathrm{H}-7$ & $6.85 \mathrm{~d}$ & $6.98 \mathrm{~d}$ & $6.96 \mathrm{~d}$ & $6.72 \mathrm{~d}$ \\
\hline H-9 & $2.66 \mathrm{~s}$ & $2.70 \mathrm{~s}$ & $2.69 \mathrm{~s}$ & $2.65 \mathrm{~s}$ \\
\hline $\mathrm{H}-10$ & $4.16 \mathrm{dq}$ & $3.40 \mathrm{ddq}$ & $3.10 \mathrm{ddq}$ & $3.35 \mathrm{ddq}$ \\
\hline H-11 a & & $2.37 \mathrm{dd}$ & $2.17 \mathrm{dd}$ & $2.07 \mathrm{dd}$ \\
\hline $\mathrm{H}-11 \mathrm{~b}$ & $6.42 \mathrm{dd}$ & $2.77 \mathrm{dd}$ & $2.27 \mathrm{dd}$ & $2.39 \mathrm{dd}$ \\
\hline $\mathrm{H}-12$ & $1.36 \mathrm{~d}$ & $1.25 \mathrm{~d}$ & $1.08 \mathrm{~d}$ & $1.23 \mathrm{~d}$ \\
\hline H-3' & $5.45 \mathrm{~d}$ & $5.46 \mathrm{~d}$ & $5.24 \mathrm{~d}$ & $5.28 \mathrm{~d}$ \\
\hline $\mathrm{H}-4^{\prime}$ & $6.28 \mathrm{~d}$ & $6.29 \mathrm{~d}$ & $6.18 \mathrm{~d}$ & $6.02 \mathrm{~d}$ \\
\hline$H-5^{\prime}$ & $6.88 \mathrm{~s}$ & $6.81 \mathrm{~s}$ & $6.71 \mathrm{~s}$ & $6.60 \mathrm{~s}$ \\
\hline $\mathrm{H}-8^{\prime}$ & $6.35 \mathrm{~s}$ & $6.39 \mathrm{~s}$ & $6.26 \mathrm{~s}$ & $6.03 \mathrm{~s}$ \\
\hline $\begin{array}{l}\mathrm{H}-10^{\prime} \\
\mathrm{H}-10^{\prime \prime}\end{array}$ & $2.02 \mathrm{~d}$ & $\begin{array}{l}5.13 \mathrm{brs} \\
5.81 \mathrm{brs}\end{array}$ & $1.54 \mathrm{~s}$ & \}$^{1.52 \mathrm{~s}}$ \\
\hline $\mathrm{H}-11^{\prime}$ & $1.41 \mathrm{~s}$ & $1.44 \mathrm{~s}$ & $1.39 \mathrm{~s}$ & $1.11 \mathrm{~s}$ \\
\hline $\mathrm{H}-12$ & $1.42 \mathrm{~s}$ & $1.43 \mathrm{~s}$ & $1.37 \mathrm{~s}$ & $1.29 \mathrm{~s}$ \\
\hline Meo & $3.81 \mathrm{~s}$ & $3.81 \mathrm{~s}$ & $3.73 \mathrm{~s}$ & $3.77 \mathrm{~s}$ \\
\hline
\end{tabular}

$J(H z)$ : Compounds (5-8) 3.4' $=10 ; 10,12=7 ; \quad 11_{a}, 11_{b}=14$.

Compound (5): $10,11_{\mathrm{a}}=9 ; \quad 10,11_{\mathrm{b}}=1$.

Compound (6): $10,11_{a}=5 ; \quad 10,11_{b}=9$.

Compound (7): $3,7=1 ; \quad 10,11_{a}=5 ; \quad 10,11_{b}=8$.

Compound $\quad(8): 3,7=1 ; \quad 10,11_{\mathrm{a}}=4,5 ; \quad 10,11_{\mathrm{b}}=10.2$ 
<smiles>C=C(C)c1cc2cc(C(C)=O)c(O)cc2o1</smiles>

1<smiles>C=Cc1cc2c(cc1OC)OC(C)(C)C=C2</smiles>

3<smiles>COc1cc2c(cc1C(C)C)C=CC(C)(C)O2</smiles>

2<smiles>CC(=O)c1cc2c(cc1O)OC(C)(C)C=C2</smiles>

4

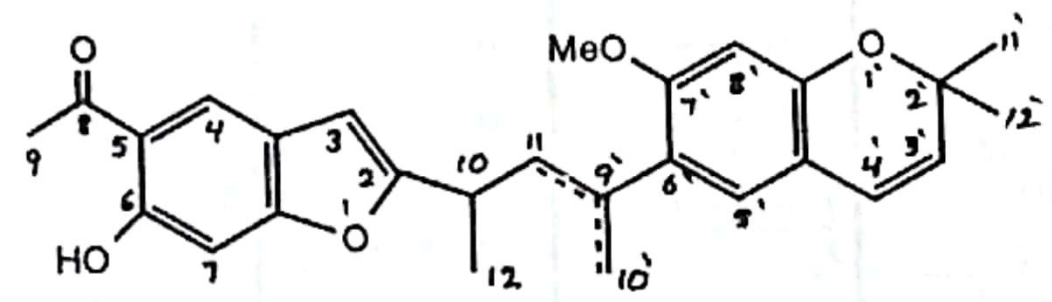

5: $R=\Delta 9,11$

6: $R=\Delta 9^{\prime}, 11^{\prime}$<smiles>COc1cc2c(cc1C(C)CC(C)c1cc3cc(C(C)=O)c(O)cc3o1)C=CC(C)(C)O2</smiles>

7: $\alpha \mathrm{Me}, \boldsymbol{B ~ O H}$

8: $\beta \mathrm{Me}, \alpha \mathrm{OH}$ 
The 'Hnmr spectrum of compound 3 (Table 1) was close to compound 2 . The disappearance of the singlet at $\delta 1.46(\mathrm{H}$ 10) and the appearance of three doublets at $\delta 5.67(\mathrm{H}-10), \delta 5.11(\mathrm{H}-10)$ and $\delta$ $6.92(\mathrm{H}-9)$ indicated the presence of a methylene group attached to $\mathrm{C}-8^{(6,8)}$.

The 'Hnmr spectrum of compound 4 (Table 1), suggested that this compound is 2,2-dimethyl-6-acetyl-7-hydroxy chromene. This assumption was deduced from the disappearance of the singlet at $\delta$ $3.81(-\mathrm{OMe})$ and the down field shift of (H-10) to $\delta 2.65^{(8)}$.

Concerning compound 7 and 8 , the IR spectra showed the same signals, $3480 \quad(\mathrm{OH}), \quad 3600, \quad 2600,1640$ for (o-hydroxyphenyl ketone), 1615 $(C=C)^{(7,10)}$.

Moreover, CIMS suggested a molecular formula $\mathrm{C}_{27} \mathrm{H}_{30} \mathrm{O}_{6}$, while the EIMS confirmed the proposed molecular formula, besides the following fragments: $\mathrm{m} / \mathrm{z} 450\left(\mathrm{M}^{+}, \mathrm{C}_{27} \mathrm{H}_{30} \mathrm{O}_{6}\right) ; 422(10 \%)$, $217\left(100 \%, \mathrm{C}_{13} \mathrm{H}_{13} \mathrm{O}_{3}\right)$. The base peak is formed by cleavage of the $\mathrm{C}_{11}-\mathrm{C}_{9}$ linkage which is in agreement with the reported data ${ }^{(7)}$. Together with the ${ }^{1} \mathrm{Hnmr}$ spectra (Table 2) these data clearly showed the structure of these compounds as: encecanescol 7 and 9-epiencecanescol $8^{(7)}$.

The ${ }^{1} \mathrm{Hnmr}$ spectra (Table 2) showed that compound 5 and $\mathbf{6}$ are similar to compound 7 and 8 , with the difference only in the extra $\mathrm{H}_{2} \mathrm{O}$ molecule in compound 7 and 8 . The $\mathrm{ms}$ spectra of these compounds confirmed the above assumption. The molecular ion peak at $\mathrm{m} / \mathrm{z} 432$ (for $\mathrm{C}_{27} \mathrm{H}_{28} \mathrm{O}_{5}$ ) and the base peak at $\mathrm{m} / \mathrm{z} 217$, confirmed that compound 5 and 6 are formed after elimination of $\mathrm{H}_{2} \mathrm{O}$ from compound 7 and 8 . The
${ }^{1} \mathrm{Hnm}$ signals of compound 5 at $\delta 6.42$ (dd, $\mathrm{H}-11$ ) indicated the olefinic protons on the double bond between $\mathrm{C}_{9}-\mathrm{C}_{11}{ }^{(7)}$, while the ${ }^{1} \mathrm{Hnmr}$ signals of compound 6 at $\delta 2.40$ (dd, H-11a), 2.77 (dd, H-1 lb), 5.13 (br s, H-10') and 5.81 (br s, H-10") indicated that the position of the double bond between $\mathrm{C} 9$ '- $\mathrm{C} 10^{\prime}{ }^{(7)}$ (Table 2).

Thus, the dimeric structure of compounds $5,6,7$ and 8 has been confirmed.

To our knowledge, compounds $\mathbf{1 - 8}$ are isolated for the first time from this plants.

The identification ${ }^{(5)}$ of $B$-sitosterol, stigmasterol and $B$-farnesene was confirmed by high field ${ }^{1} \mathrm{Hnmr}, \mathrm{ms}$, and co-tlc.

Acknowledgement : The authors thank late Prof. Dr. F. Bohlmann and Dr. J. Jakupovic, TU. Berlin, Germany for providing the plant material and the spectral analysis.

\section{REFERENCES}

(1) Robinson, H.; Smithson. Contrib. Botany, 51, 48 (1981).

(2) Geissman, T.A. and Mukherjee, R.; J. Org. Chem., 33, 656 (1968).

(3) Sims, J.J. and Bergmann, K.A.; Phytochemistry, 11, 444 (1972).

(4) Njeldanes, L. and Geissman, T.A.; Phytochemistry, 8, 1293 (1969).

(5) Bohlmann, F.; Jakupovic, J. and Zdero, C.; Phytochemistry, 17, 2034 (1978).

(6) Bolmann, F. and Grenz, M.; Chem. Ber., 10, 295 (1977).

(7) Bohlmann, F.; Tsankova, E.; Jakupovic, J.; King, M. and Robinson, H.; Phytochemistry, 22, 557 (1983).

(8) Bohlmann, F. and Grenz, M.; Chem. Ber., 10390 (1970). 
(9) Proksch, P. and Rodriguez, E.; Phytochemistry, 22, 2335 (1983).

(10) Pretsch, E.; Seibl, J.; Simon, W. and Clerc, T.; "Spectral Data for Structure Determination of Organic Compounds". Springer-Verlag, Berlin, pp. 1, 130 (1983).

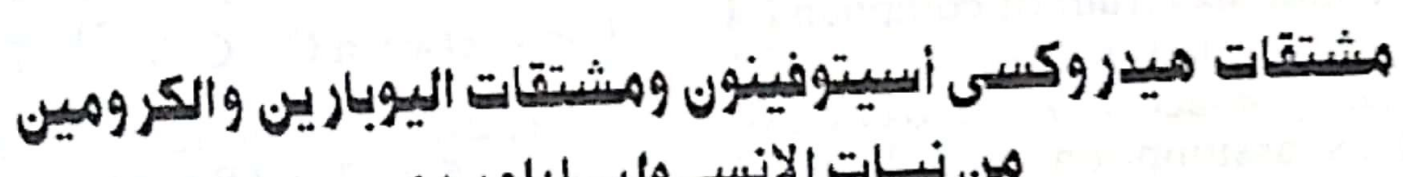

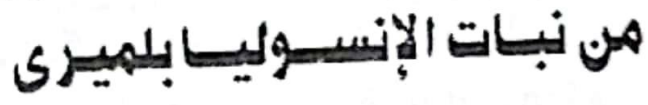

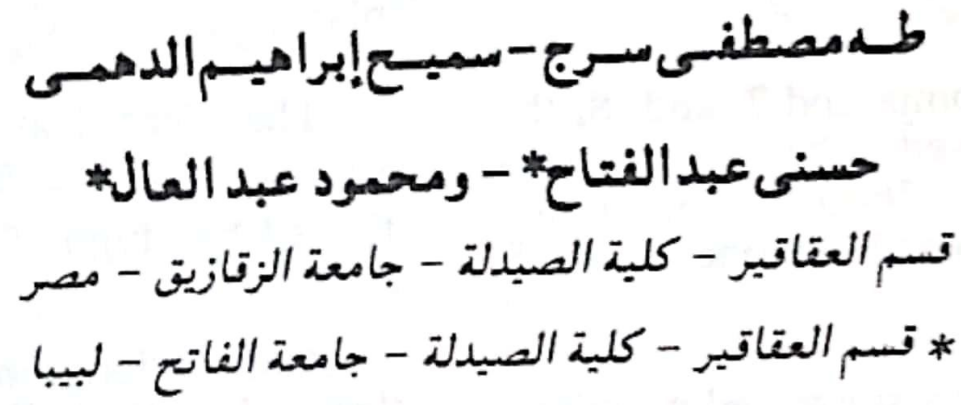

يتبع نبات الإنسولبا بلمبرى العائلة المركبة ربشتهر هذا النبات بأحتوا هاء على مشتقات الهيدروكسى أسبتوفينون

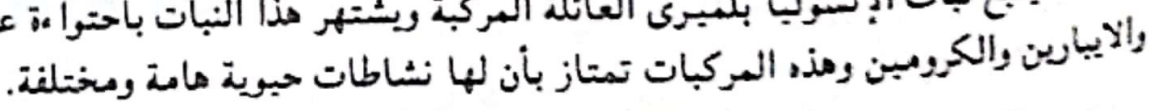

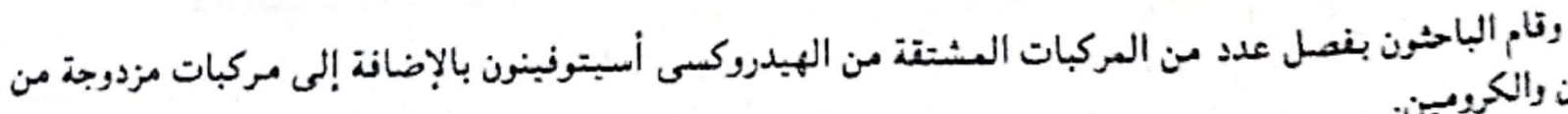

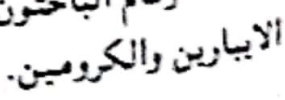

وتم التعرف على التركيب الكمبانى لهذه المركبات بدراسة الصفات الطبعبة والكيميانية والطيفية لها. 